\title{
Ecological analysis of the distribution and socio-spatial context of homicides in Porto Alegre, Brazil
}

\author{
Simone M. Santos ${ }^{\mathrm{a}, *}$, Christovam Barcellos ${ }^{\mathrm{a}}$, Marilia Sá Carvalho ${ }^{\mathrm{b}}$

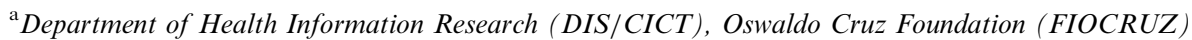 \\ ${ }^{\mathrm{b}}$ Department of Epidemiology and Quantitative Methods (DEMQS/ENSP), Oswaldo Cruz Foundation (FIOCRUZ)
}

\begin{abstract}
Over the last decade, the number of homicides in Porto Alegre has increased to the point where external causes are now the main group of causes of death in the 5-34-year age group. Preventing these deaths depends fundamentally on identifying factors related to excess violence in population groups. The overall aim of this study is to analyse the spatial distribution of homicide victims by place of residence in Porto Alegre, the capital of the southernmost Brazilian State of Rio Grande do Sul, in 1996, in order to identify and understand the socio-spatial context. Demographic and socioeconomic indicators based on the 1991 census and 1996 population count were used to build a multivariate classification characterizing the 1851 census tracts. Homicides occurring in 1996 were located using the municipality's Geographic Information System. Four socioeconomic groups were identified, mainly differentiated by housing indicators. Small areas on the urban periphery in which slums (favelas) are concentrated presented higher homicide rates. Homicide rates were lower in the two groups with higher income and educational level. The second step was to classify the census tracts according to the homicide indicator. In this case, areas were differentiated by the number of household inhabitants per room, income, schooling, and median age. We conclude that the multivariate socioeconomic classification presents a limited capacity to identify populations exposed to homicides, suggesting that socioeconomic conditions themselves do not determine violent behaviour. On the other hand, the spatial methods allowed us to identify small areas where deaths are concentrated and whose populations should receive special attention in planning measures to prevent violent deaths.
\end{abstract}

(C) 2004 Elsevier Ltd. All rights reserved.

Keywords: Violence; Homicide; Quality of life indicators; Geographic information system; Spatial analysis

\section{Introduction}

In Brazil, the second largest group of causes of death is external causes of injury and poisoning, resulting in 120,000 deaths per year, surpassed only by the

\footnotetext{
*Corresponding author. Departamento de Informações em Saúde (CICT/FIOCRUZ), Avenida Brasil, 4365-Rio de Janeiro-RJ 21045-900, Brazil. Tel.: + 55-21-38653258; fax: + 55-213865-3240.

E-mail address: smsantos@fiocruz.br (S.M. Santos).
}

cardiovascular diseases group. Homicides are the leading cause in the group of external causes. In males $15-34 \mathrm{yr}$ old and in some Brazilian metropolises, this is the main cause of death overall (Mello Jorge et al., 1997).

In the city of Porto Alegre (Rio Grande do Sul State, Brazil; see location map, Fig. 1), homicides have been the main external cause of death from 5 to $49 \mathrm{yr}$ of age since 1995 and the fourth most frequent cause overall, with an increasing rate in recent years. The male/female ratio is eight to one (Aerts et al., 1996). Prevention of 


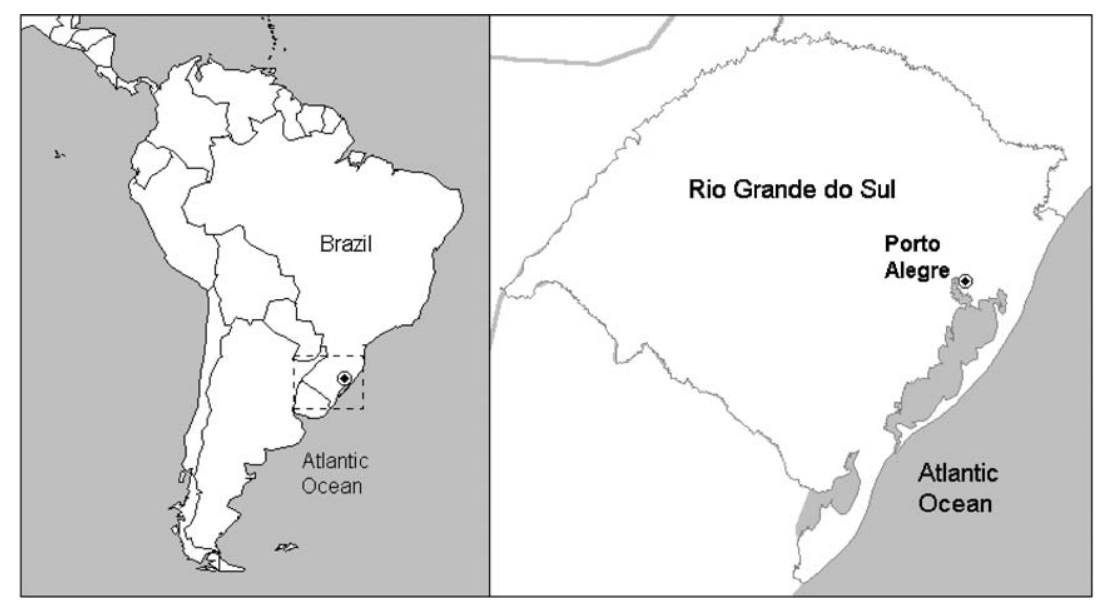

Fig. 1. Location map of the city of Porto Alegre, Brazil.

homicides is a priority for local government in order to prevent the increase observed in other major Brazilian cities (Souza and Minayo, 1995; Vermelho and Mello Jorge, 1996; Soares, 1996; Macedo et al., 2001). According to the 1991 population census, Porto Alegre had a total of $1,288,879$ inhabitants in 82 neighbourhoods. The city is an important industrial and business centre in Southern Brazil and is the ninth largest city in the country.

Homicides are the most critical outcome of violence, resulting from a complex interaction between individual attributes and the social context where the violence occurs. Prevention, although difficult, can break the causal chain of violence. In order to better understand the problem as a whole, the first step is to model the context in which violence occurs and to identify the areas where these situations share specific dynamics. Precisely locating population groups where these factors are concentrated is essential to develop environmental, educational, and social welfare measures (Carvalho et al., 1997; Harries, 1997).

There is a spatial dimension in the dynamics of the social groups, characterized by the convergence of the numerous intervening social, economic, and cultural variables that shape the city and are influenced by it. Some Marxist authors (Harvey, 1973; Castells, 1976; Lefebvre, 1980) define urban space as a "projection on the background of social relationships". This urban space is also a place of confrontation, which includes the demands raised by social movements (Castells, 1976) and the actions by the state, acting either to buffer or aggravate existing social inequalities (Harvey, 1973). According to the same authors, spatial segregation in the cities also produces different life styles among social groups (Pearlman, 1976). More recent studies have observed that reversal of social inequality in cities has not taken place as expected but, on the contrary, has been aggravated by the lack of appropriate public policies and stigmatization of social minority groups in the urban space (Valladares, 1998; Wacquant and Wilson, 1989). Extreme segregation produces neighbourhoods of "advanced marginality", characterized by unemployment, lack of state investments, and the predominance of ethnic groups with low social mobility (Pearlman, 1976). In these neighbourhoods, called the "black belt" in North America, "slums" in Rio de Janeiro and Bogotá, and "banlieue" in France, intense and permanent social conflicts take place (Wacquant, 1992).

Numerous epidemiological studies have demonstrated the role of social inequalities in the distribution of disease and mortality (Centerwall, 1974; OnwuachiSaunders and Hawkins, 1993; Soares, 1996; Strohmeier, 1998; Zaluar, 2000). In the underdeveloped world, where vast metropolitan peripheries suffer simultaneously from poverty, low educational levels, and lack of social services, this inequality assumes dramatic proportions. Contemporary North American studies (Wallace, 1993) analyze the breakdown of social networks and the spread of epidemics and crime in poor ghettos in such metropolises as New York City.

Several epidemiological studies in Brazilian cities have demonstrated an association between socioeconomic indicators and health problems (Akerman et al., 1994; Freitas et al., 2000; Lima and Ximenes, 1998; Silva et al., 1999; Paim et al., 1999; Macedo et al., 2001), showing that socially deprived populations present higher rates of various causes of death, including chronic and infectious diseases as well as external causes.

However, most of these studies present two major limitations. The first is the use of synthetic social indicators such as the Human Development Index (HDI) (UNDP, 1999). This concept of "human development" has substituted the use of specific economic parameters (such as the Gross National Product) to measure development. Many papers on an intra-urban 
scale have used the HDI and other similar indicators to estimate inequality and its consequences for health. Although useful for efficiently discriminating poor and rich areas, such compound indicators lack specificity for the conceptual modelling involved in the genesis of the problem.

The second limitation is the lack of geographic precision, due to poor cartographic databases, hampering the studies in their comparison of large areas such as administrative districts, where different population groups are mixed. However, greater homogeneity in the population profile is usually achieved (but with increased statistical instability) by using smaller population units. In small areas such as census tracts, homicides are a rare event and the naïve estimation of risk obtained through the number of deaths divided by the population is not the best estimator, as the lack of deaths in any area does not mean zero risk, but only random fluctuation. One of the aims of this study is to propose a methodology for estimating smoothed homicide rates, obtained through the interpolation of homicide and population densities.

Furthermore, to study the spatial distribution of the homicide rate in Porto Alegre in 1996 and its relationship to socioeconomic and demographic indicators, two complementary approaches were used to partition the city. One is based on characterization of the city to identify areas where risk factors for violence are concentrated, using the so-called socioeconomic areas; the other begins by identifying areas with a high concentration of homicide victims by place of residence, called homicide rate areas, in order to characterize vulnerable social groups. Comparison of these two approaches, the first using the city profile to characterize critical homicide areas, and the second using the homicide spatial distribution to characterize living conditions, guided our discussion of the stratification of urban areas based on socioeconomic profiles. This paper is not intended to establish a causal relationship between violence and socioeconomic indices, but merely to identify the best indicators for revealing high-risk areas. In addition, using "place" as an analytical category will not reveal the causes of violent acts but will help understand the causes of increased incidence of events (Rose, 1995), which is our key interest.

\section{Methods}

Most aspects presented in the introduction are not easily converted into variables by which associations can be studied. We selected some covariates from the available databases to construct the indicators, in order to explicitly study the relationship proposed in our working hypothesis.
Based on this proposal, we support the theory that rather than placing the determinants of homicides exclusively in the local area, one should identify it in the social processes generated by the political, economic, and ideological structures that reproduce and maintain the prevailing social formation. Such processes turn the residents of low-income areas into either victims or perpetrators of conflicting situations, in a context that also hinders the search for alternatives or social support. Solutions vary from one area to another according to a set of attributes of the resident population, resulting in differences in homicide rates.

\section{Data}

The cartographic databases and health information supporting this study were provided by the Health Information Unit (CEDIS) of the Porto Alegre Municipal Health Authority. The information layers used were street centre lines and the 1851 census tract (CT) polygons from the 1991 population census and the neighbourhood and city limits. A few islands belonging to Porto Alegre were excluded from the analysis.

Using the 1991 demographic census and the 1996 population count (IBGE, 1998) data, 11 indicators were selected, based on both their adequacy for the conceptual model and a principal component analysis (Table 1). In the demographic census, households are classified as permanent or temporary residences and located in urbanized or slum areas, the latter generally lacking proper sanitation systems and concentrating low-income urban populations.

The mortality information system was the source of the 286 homicide records, codes X85 to Y09, in the 10th revision of the international classification of diseases (WHO, 1995). Homicides were geocoded to points using the residential address and the street map using GIS MapInfo $^{\text {TM }}$ (1995), with a failure rate of less than $5 \%$.

\section{Statistical methods}

Cluster analysis used the K-means algorithm (Hartigan, 1975), available in the SPSS ${ }^{\mathrm{TM}}$ program (1997), and generated four distinct groups demarcating four different socioeconomic areas.

A kernel smoother was applied to the spatial location of homicides. This technique consists of an estimate of spatial point density of events over an area, smoothing out excess variability, but retaining local patterns, thus generating a "risk surface" (Bailey, 1994). The basic equation to estimate the intensity $\hat{\lambda}_{\tau}(s)$ of the process, in each cell of a regular grid dividing all region is:

$\hat{\lambda}_{\tau}(s)=\sum_{i=1}^{n} \frac{1}{\tau^{2}} k\left(\frac{\left(s-s_{i}\right)}{\tau}\right)$, 
Table 1

Socioeconomic indicators of census tracts

\begin{tabular}{|c|c|}
\hline Name of indicator ${ }^{a}$ & Indicator \\
\hline \multicolumn{2}{|l|}{ Demographic indicators } \\
\hline Population & Total population in 1996 \\
\hline Density & Population density in 1996 \\
\hline Growth & Population growth between 1991 and 1996 \\
\hline \multicolumn{2}{|c|}{ Housing conditions indicators ${ }^{\mathrm{b}}$} \\
\hline Water & Proportion of households without indoor running water and without public water supply system \\
\hline Sanitation & $\begin{array}{l}\text { Proportion of households with no public sewage system, discharge into non-draining septic } \\
\text { tank, rudimentary tank, open-air ditch, or no sanitation installed }\end{array}$ \\
\hline Waste & Proportion of households without domestic waste collection \\
\hline Rented households & Proportion of households occupied on a rental basis \\
\hline “SLUMS” households & Proportion of households located in "slums" (slums) \\
\hline Inhab./room & Mean number of inhabitants per room in the households \\
\hline \multicolumn{2}{|c|}{ Indicators of the resident population in each census tract ${ }^{\mathrm{c}}$} \\
\hline Woman head & Proportion of female heads-of-households \\
\hline Men/women & Ratio of total male population to total female population residing in the census tract \\
\hline Illiteracy & Illiterate proportion of the population ( $15 \mathrm{yr}$ or older) \\
\hline High school & Proportion of heads-of-households with high school diploma or higher \\
\hline School $<4$ yr & Proportion of heads-of-households with $3 \mathrm{yr}$ of schooling or less \\
\hline Income $<=2 \mathrm{MW}$ & Proportion of heads-of-households with income twice the minimum wage or less \\
\hline Income $>20 \mathrm{MW}$ & Proportion of heads-of-households with income 20 times the minimum wages or greater \\
\hline Mean income & Mean income of head of household (in times the minimum wage) \\
\hline Median women & Median age, women \\
\hline Median men & Median age, men \\
\hline
\end{tabular}

${ }^{\mathrm{a}}$ The selected indicators appear in bold print.

${ }^{\mathrm{b}}$ All the proportions were calculated using total households in the census tract as the denominator.

${ }^{\mathrm{c}}$ The proportions were calculated on the basis of the total heads-of-households in the census tract.

where $k()$ is the density probability function applied, in our case a Gaussian distribution; $\tau$ is the band width, responsible for the degree of smoothing obtained, which in this case was $2 \mathrm{~km} ; s_{i}$ are observed points; and $n$ is the total number of events.

A kernel ratio was used to control for the variation in the number of people exposed. This is calculated dividing the kernel intensity of homicides and the kernel of the population counts in each cell of the grid, thus estimating a homicide rate surface. All statistical analysis was performed with S-Plus ${ }^{\mathrm{TM}}$ (STATSCI, 1993).

The risk surface was included as a layer in the GIS. The mean value of the kernel ratio of the grid cells inside each census tract was then used as the smooth estimator of the homicide rate. The areas were then classified, according to the quintiles of the homicide rate, into three groups: upper $20 \%$, intermediate $60 \%$, and lower $20 \%$. Analysis of variance was used to assess differences in the levels of the socioeconomic indicators among the classes defined by the homicide rate areas, thus identifying indicators which discriminate the different homicide levels.

\section{Results}

In 1996, 286 homicides were committed, with a male/ female ratio of nine to one. Some $51 \%$ of the victims were single and $48 \%$ were under $29 \mathrm{yr}$ of age. Firearms were used to perpetrate $80 \%$ of the homicides (IDC Codes X95 and X94). In parallel with this research, another study estimated the distance between the victim's place of residence and the crime site; in $67.3 \%$ of the homicides this distance was $<1 \mathrm{~km}$, in $50 \%$ $<310 \mathrm{~m}$, and in $29.1 \%$ the homicide occurred in the victim's residence (Santos et al., 2001).

\section{Characterizing the socioeconomic areas}

Using cluster analysis, the census tracts were classified into four groups, the profiles of which are shown in Table 2. The proportions of "slum" households and total households with inadequate sanitation, followed by the proportion of rented households, number of inhabitants per room, and proportion of heads-ofhouseholds with $3 \mathrm{yr}$ of schooling or less, were the 
variables that most contributed to the final classification. The spatial distribution of the socioeconomic areas is mapped in Fig. 2. The groups are briefly described as follows.

Group A comprises the largest number of census tracts (849). The group covers a broad area of the city, around the city centre, with the highest socioeconomic status, i.e., educational level slightly higher than the average and a greater proportion of heads-of-household with an income greater than 20 times the index minimum wage.

Group B comprises 597 tracts, located in the area of greatest urban concentration, predominantly in the western sector of the city. This is the group with the 


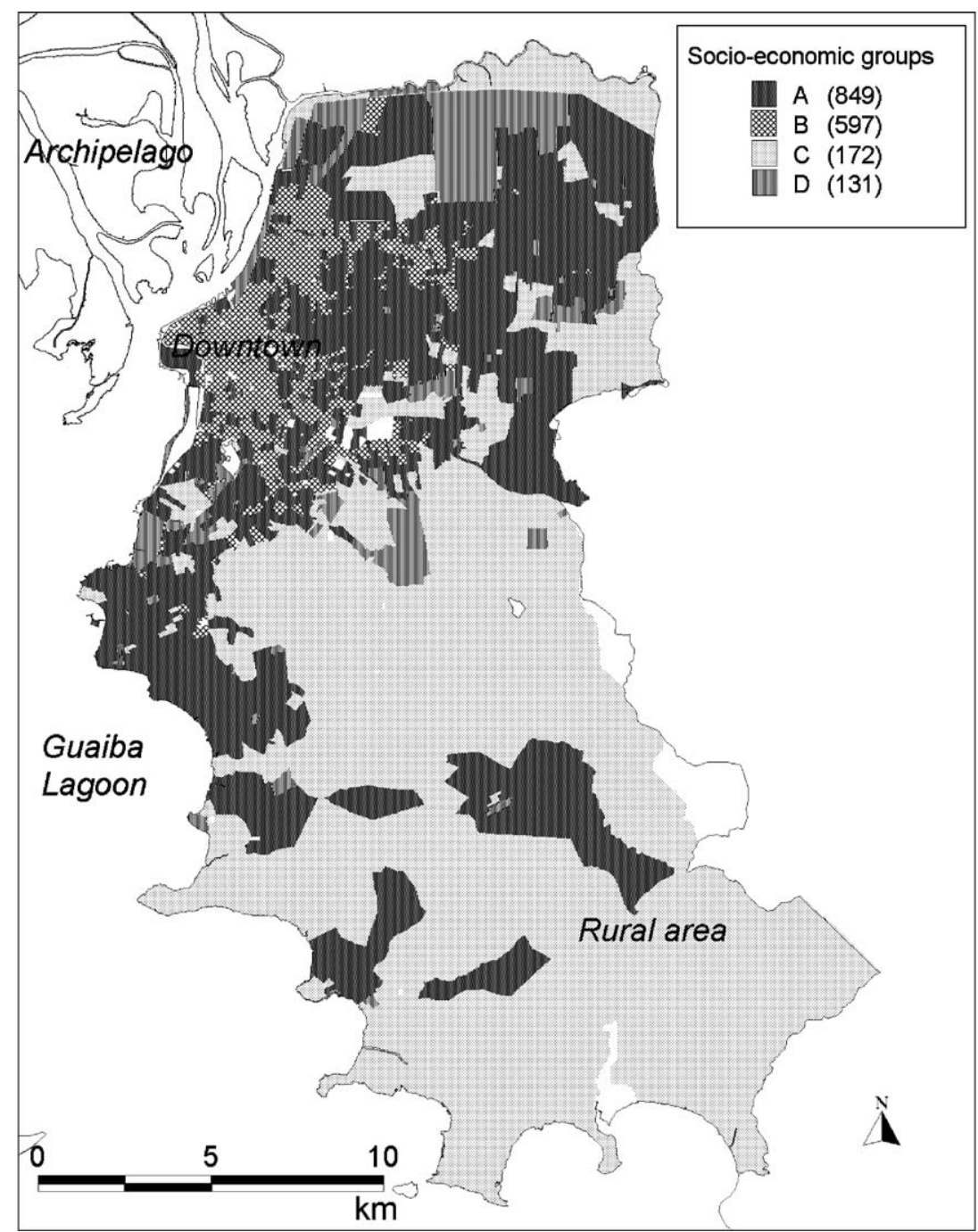

Fig. 2. Map of socioeconomic small areas, Porto Alegre, 1991.

However, Group A showed more tracts with atypically high values. Homicide rates in each of these groups present statistically significant differences according to the Tukey test post hoc, with the exception of Groups A and $\mathrm{C}$, with similar observed values.

\section{Characterizing the homicide rate areas}

The census tracts were classified into three groups, according to the homicide level: upper.Q (quintile); intermediate, formed by joining the intermediate quintiles, in which $60 \%$ of the census tracts are concentrated; and lower.Q, the lower quintile of the distribution. The same indicators used in the cluster analysis were employed to describe the three strata (Table 3). Fig. 3 shows the homicide rate areas.
Census-tract groups with higher homicide rates (now using the homicide rate classification) present poor socioeconomic conditions, i.e., variables indicating deprived conditions in all areas: insufficient sanitation, income, and education, in addition to overcrowding and substandard housing. The proportions of households with inadequate sanitation and "slum" housing show the highest mean values. These areas also present a low educational level, the lowest proportion of heads-ofhouseholds with monthly incomes greater than 20 times the minimum wage, and low median male age. On the other hand, low homicide rate areas were associated with more schooling, higher income, and better housing. The main discriminating variables (highest $F$-values in the analysis of variance) were the number of inhabitants per room and head-of-household's income. The mean proportion of rented households is less in the upper 
Table 3

Profile of homicide rate groups and ratio of variance between/within groups $(F)$ for socioeconomic indicators

\begin{tabular}{|c|c|c|c|c|c|}
\hline \multirow[t]{2}{*}{ Indicator } & \multicolumn{3}{|c|}{ Mean indicators in the group } & \multirow[t]{2}{*}{ Total mean } & \multirow[t]{2}{*}{$F$-value $^{\text {b }}$} \\
\hline & Lower Q. & Intermediate & Upper Q. & & \\
\hline Inhabit./room & 0.47 & 0.57 & 0.78 & 0.59 & 240.54 \\
\hline Mean income & 9.94 & 6.63 & 3.58 & 6.69 & 204.20 \\
\hline School. $<4$ yr & 9.64 & 12.72 & 26.02 & 14.76 & 188.25 \\
\hline Income $>20 \mathrm{MW}$ & 12.56 & 5.52 & 1.54 & 6.14 & 176.51 \\
\hline Median age men & 30.96 & 28.26 & 23.97 & 27.95 & 170.29 \\
\hline Median age women & 34.52 & 31.77 & 26.61 & 31.29 & 156.52 \\
\hline Rented households & $24.23^{\mathrm{a}}$ & $23.84^{\mathrm{a}}$ & 12.62 & 21.68 & 90.57 \\
\hline "Slum" households & 1.93 & 5.66 & 22.24 & 8.22 & 73.19 \\
\hline Male/female ratio & 0.83 & 0.84 & 0.91 & 0.86 & 47.07 \\
\hline Sanitation & $12.05^{\mathrm{a}}$ & $13.82^{\mathrm{a}}$ & 31.84 & 17.05 & 59.99 \\
\hline Women head house & $29.17^{\mathrm{a}}$ & $30.34^{\mathrm{a}}$ & 25.64 & 29.17 & 29.63 \\
\hline Homicide rate & 2.88 & 11.13 & 30.46 & 13.32 & \\
\hline Number of tracts & 352 & 1048 & 349 & 1749 & \\
\hline
\end{tabular}

${ }^{a}$ Groups for which the differences between means were not significant at the 0.05 level, according to the Tukey test post hoc.

${ }^{\mathrm{b}}$ All $F$-values are significant $(\alpha<0.01)$.

quintile and similar in the other two groups. The number of inhabitants per room shows increasing median values from the lower to the upper quintiles. The male/female ratio is higher in the upper quintile and similar in the other groups.

All income and schooling indicators decrease as the homicide rates increase. Median age for both males and females differs greatly among the groups, but this may be more a consequence than a cause of excess mortality in younger groups. All socioeconomic indicators within homogeneous homicide rate groups showed great variation, with numerous atypical values, and the difference between groups was small, usually presenting overlapping values.

\section{Discussion}

The pattern observed in the socioeconomic areas showed higher homicide rates in Group D, where socioeconomic conditions are the worst. Group C also displayed unfavourable socioeconomic indicators, but the group comprises rural areas of the municipality and had a lower homicide rate than Group D. There was an important difference in the homicide rates between Groups A and B, despite their similar socioeconomic conditions. Group B had the lowest homicide rates in Porto Alegre. If the homicide profile were determined only by socioeconomic status, Group A, with slightly better socioeconomic conditions than Group B, would present a similar rate to the latter. The geographic characteristics of the two groups are also different: Group B includes areas with the city's most densely populated, traditional urban area, while Group A covers a peri-urban and more recently settled area.

Group C homicide rates may be overestimated due to its rural nature and low population density. Although the interpolation method used smoothed random fluctuation where the population is small, in extensive areas of very low demographic density and very few census tracts, interpolation is not sufficient to prevent extremely high values where only one death occurred.

The method for estimating the homicide rate, based on the ratio of density surfaces, proved suitable for visualizing the process and differentiating the small areas, regardless of political and administrative macroborders. Visualizing on the map was essential to grasp the fluctuation of homicide rates in areas with small populations. The main advantage of the method was its flexibility, where point event data, without any pre-set unit of aggregation in a short time period (only one year), were related to small-area population data, thus eluding the small-area rate instability, without losing spatial resolution. The main aim of this study-to identify the areas where homicide victims live and their socioeconomic context-required the choice of the analytical scale, capable of identifying intra-urban structural phenomena, meanwhile differentiating areas containing specific population groups. The use of point location of residences and census tracts polygons as the basis for this characterization allowed classification of reasonably homogeneous areas, while displaying sufficient variation between them.

Socioeconomic deprivation is often identified as a major determinant of violence, usually associated with 


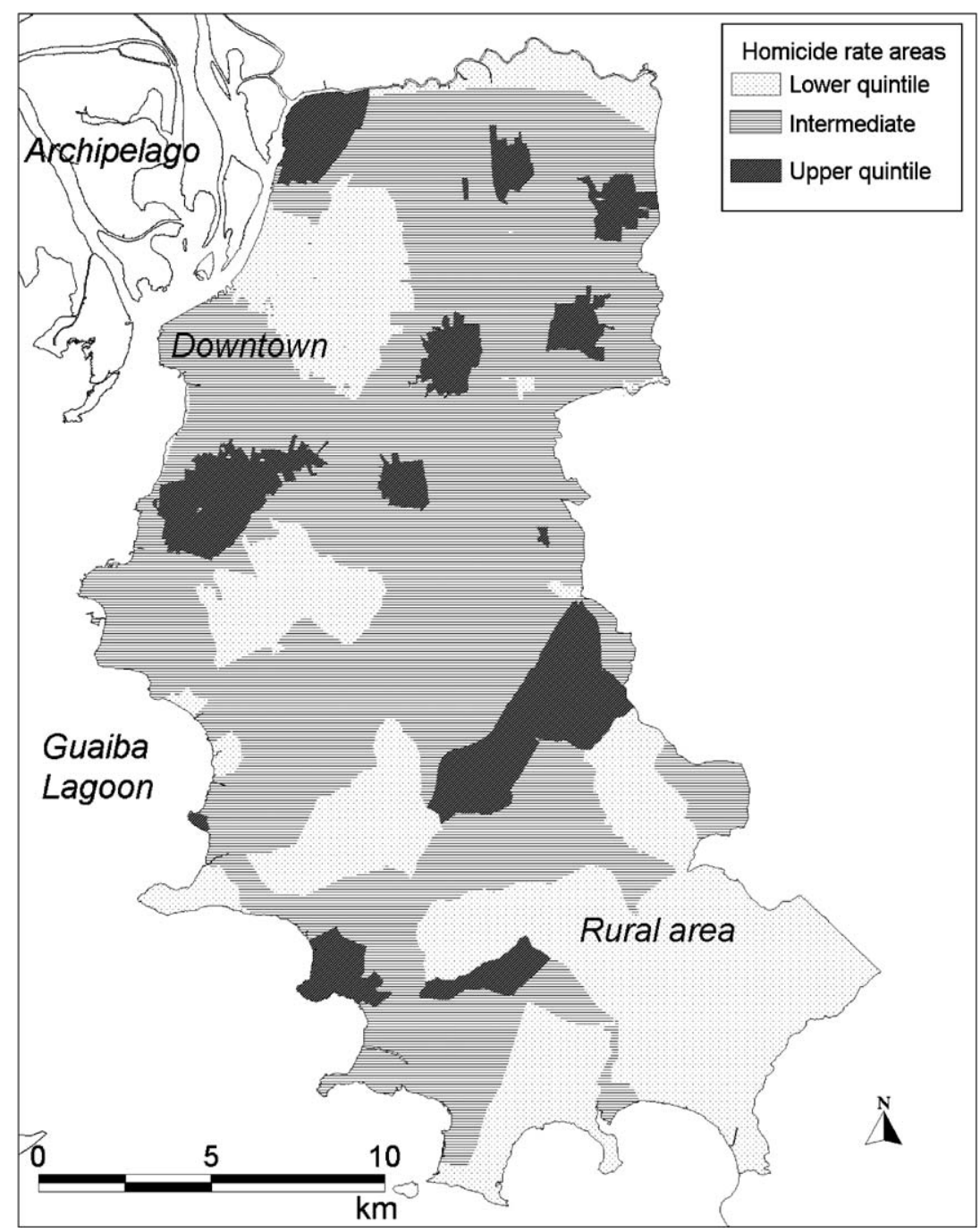

Fig. 3. Map of homicide rate small areas, Porto Alegre, 1996.

variables such as race, class, and education, in studies focusing on the individual level (Blane, 2001). The concentration of socially deprived groups in some areas of the city is one of the components leading to an unequal spatial distribution of violence in urban areas (Strohmeier, 1998). However, contextual aspects must be considered when analyzing aggregate data (DiezRoux, 1998). Recent studies have shown that, as compared to mean income, social inequalities show a stronger association with violence. For instance, homogeneous poor populations present a lower incidence of violent events than areas with heterogeneous composition of poor and rich populations (Kawachi et al, 1997; Szwarcwald et al., 2000). Therefore, low socioeconomic levels themselves do not necessarily involve a high homicide rate. Choice of place of residence is condi- tioned by income and socio-cultural profile, but is not deterministic, and places are not entirely homogeneous. Besides, the phenomenon called "poverty" can be understood as a set of quite diverse conditions: rural and urban poverty, as well as slums and metropolitan poverty belts, are different processes and produce different epidemiological profiles, despite belonging to the same broad social category of poverty. It is striking that the three most important variables in the cluster analysis, the proportion of "slum" residences, households with inadequate sanitation, and rented households, showed smaller differences among the homicide strata. The proposed indicator of family structure (proportion of women heads-of-households) displayed small variation among groups and was not helpful for discriminating the homicide risk areas. 
Family structure and other collective protective or risk factors for homicides could not be assessed in this study, since we worked only with census indicators. The ideal analysis would include distribution of the number of children per family, couples without children, multifamily households, and single parents. It was only possible to analyse the following indicators: median age, male/female ratio, female heads-of-household, and rented households as proxies of different socio-demographic situations, themselves possibly related to family structure. The lack of more specific indicators is a real problem and should be addressed in local studies with primary source data.

The multivariate classification of census tracts was insufficiently accurate to predict homicide risk, possibly due to the limited scope of available socioeconomic variables. Other intervening factors may be acting in the socio-spatial context where the homicide victims resided: aspects such as behaviour patterns of vulnerable groups, access to urban facilities related to public security policies, the presence and structure of organized crime, and other sources of reinforcement and structuring of citizens' social support networks (Beato-Filho et al., 2001; Harries, 1997).

This study showed that in Porto Alegre, interactions among demographic features, urban facilities, and socioeconomic factors have diverse results expressed locally according to the factors present in each area. Violent behaviour is not fully determined by adverse socioeconomic conditions, and one single model for all areas cannot explain its distribution. In each place, different social factors will interact, promoting or preventing violence. Population density and social exclusion are examples of indicators that interact to create a violent context. As shown in this paper, areas with lower population density present fewer homicides, even in the presence of deprived socioeconomic conditions. These findings reinforce the need to improve information systems and data analysis methods to simultaneously deal with place-specific and individual characteristics.

Furthermore, appropriate social policies need to be implemented at both the local and national levels. Social investments by municipal administrators in Brazil in the last decade are already producing local responses in the form of improved access to basic public services such as sanitation, health, and education (Aerts et al., 1996). However, one basic step in the process of improving quality of life is the implementation of social policies at the State and Federal levels to deal with unemployment and income inequalities. Reform of the law enforcement and legal system are also essential (Minayo, 1994). In the words of Alba Zaluar (2000), which are shared by many of those reflecting on violence and society in Brazil, "A fair, democratic country cannot exist without such policies. In an exclusionary social context, penalty is imposed in terms of access, not only to material goods, but also to employment, health, justice, education, leisure, and personal development."

\section{Acknowledgements}

This study was funded by the Brazilian Council for Research Development (CNPq) and PAHO grants for Public Health Posgrade Tesis Finantial Support Program in Latin America and Caribean. We are grateful to anonymous referees for helpful comments on earlier drafts.

\section{References}

Aerts, D., Flôres, R., Sant'anna, A., Cunha, J., Hilgert, C., 1996. Sistema de informação sobre mortalidade'. PRÁ SABER: informações de interesse à saúde 1 (2), 25-32 SMS/ CEDIS, Porto Alegre, RS.

Akerman, M., Stephens, C., Campanario, P., Maia, P.B., 1994. Environment and health: an analysis of Intra-Urban differentials in the city of S. Paulo, Brazil. Revista de Saúde Pública 28 (4), 320-325.

Bailey, T.C., 1994. Review of statistical spatial analysis in GIS. In: Fotheringham, S., Rogerson, P. (Eds.), Spatial Analysis and GIS. Taylor and Francis Ltd., London, pp. 13-44.

Beato-Filho, C.C., Assunção, R.M., Silva, B.F.A., 2001. Homocide clusters and drug traffic in Belo Horizonte, Minas Gerais State, Brazil from 1995 to 1999. Cadernos de Saúde Pública 17 (5), 1163-1171.

Blane, D., 2001. Socioeconomic health differentials. International Journal of Epidemiology 30, 292-293.

Carvalho, M.S., Cruz, O.G., Nobre, F.F., 1997. Risk Profile: multivariate cluster analysis of urban small areas based on Socioeconomic indicators-census tracts from the Greater Rio de Janeiro Metropolitan area. Cadernos de Saúde Pública 13 (4), 435-445.

Castells, M., 1976. La Cuestion Urbana. Ed. Siglo Veintiuno. 5a ed. Mexico. 517pp.

Centerwall, B.S., 1974. Race, socioeconomic status, and domestic homicide, Atlanta, 1971-72. American Journal of Public Health 74 (8), 813-815.

Diez-Roux, A.V., 1998. Bringing context back into epidemiology: variables and multilevel analysis. American Journal of Public Health 88, 216-222.

Freitas, E.D., Paim, J.S., Silva, L.M.V., da Costa, M.C.N., 2000. Trends and spatial distribution of mortality from external causes in Salvador, Bahia State, Brazil. Cadernos de Saúde Pública 16 (3), 109-118.

Harries, K., 1997. Social stress and trauma, synthesis and spatial analysis. Social Science and Medicine 45 (8), 1251-1264.

Hartigan, J.A., 1975. Clustering Algorithms. Wiley, New York.

Harvey, D., 1973. Social Justice and the City. The Johns Hopkins University Press, Baltimore.

IBGE, 1998. Censo Demográfico de 1991 e Contagem Populacional de 1996. Fundação Instituto Brasileiro de Geografia e Estatística. 
Kawachi, I., Kennedy, B.B., Lochner, K., Pothrow-Smith, D., 1997. Social capital, income inequality and mortality. American Journal of Public Health 87 (9), 1491-1498.

Lefebvre, H., 1980. La Revolucion Urbana. Ed. Alianza Editorial. Madrid. 198pp.

Lima, M.L.C., Ximenes, R., 1998. Violence and death: differentials in mortality from external causes in Recife, Pernambuco, Brazil, 1991. Cadernos de Saúde Pública 14 (4), 829-840.

Macedo, A.C., Paim, J.S., Silva, L.M.V., 2001. Violence and social inequalities: mortality rates due to homicides and life conditions in Salvador, Brazil. Revista de Saúde Pública 35 (6), 515-522.

MapInfo, 1995. Professional Version 4.0. Copyright. MapInfo Corporation.

Mello Jorge, M.H.P., Gawryszewski, V.P., Latorre, MR.D.O., 1997. Analysis of mortality data. Revista de Saúde Pública 31 (4Supl.), 5-25.

Minayo, M.C.S., 1994. Inequality, violence, and ecology in Brazil. Cadernos de Saúde Pública 10 (2), 241-250.

Onwuachi-Saunders, C., Hawkins, D., 1993. Black-white differences in injury. Race or social class? AEP 3 (2), $150-153$.

Paim, J.S., Costa, M.C.N., Mascarenhas, J.C.S., Silva, L.M.V., 1999. The distribution of violence: mortality due to external causes in Salvador, Brazil. Revista Panamericana de Salud Publica 6 (5), 321-332.

Pearlman, J., 1976. The Myth of Marginality: Urban Poverty and Politics in Rio de Janeiro. University of California Press, Berkeley.

Rose, G., 1995. Individuos enfermos y poblaciones enfermas. Boletín Epidemiológico. OPAS, 6 (3), 1-8.

Santos, S.M., Barcellos, C., Carvalho, M.S., Flores, R., 2001. Spatial clusters of violent deaths in Porto Alegre, Rio Grande do Sul, Brazil, 1996. Cadernos de Saúde Pública 17 (5), 1141-1151.

Szwarcwald, C.L., Bastos, F.I., Barcellos, C., Pina, F., Esteves, M.A., 2000. Health conditions and concentration of poverty: a study in Rio de Janeiro, Brazil. Journal of Epidemiology and Community Health 54, 530-536.

Silva, L.M., Paim, J.S., Costa, M.C.N., 1999. Inequalities in mortality, space and social strata in Brazil. Revista de Saúde Pública 33 (2), 6-97.
Soares, L.E., 1996. Criminalidade urbana e violência: o Rio de Janeiro no contexto internacional. In: Soares, L.E. (Ed.), Violência e política no Rio de Janeiro. Rio de Janeiro: Relume Dumará, ISER.

Souza, E.R., Minayo, M.C.S., 1995. O impacto da violência social na saúde pública do Brasil. In: Minayo, M.C.S. (Ed.), Os Muitos Brasis: saúde e população na década de 80. HUCITEC-ABRASCO, São Paulo-Rio de Janeiro.

SPSS, 1997. Release 8.0.0. Copyright SPSS Inc., 1989-1997.

STATSCI, 1993. Statistical Science, Inc. S-Plus for Windows user's manual. Version 3.1, Seattle, Statistical Science, Inc.

Strohmeier, K.P., 1998. Determinants of Urban Violence and their Interlinkages: an analysis of ecological distributions and correlations. Pilot Project: Ruhrgebiet, paper no. 3, Meeting of the Consultative Group on Urban Health Research, WHO, Kobe, Japan.

UNDP, 1999. Desenvolvimento Humano e Condições de vida: Indicadores Brasileiros. Programa das Nações Unidas para o desenvolvimento (PNUD), 140 pp., Brasília.

Valladares, L., 1998. The favela revisited: the poor from community to violence. Annals of the International Sociological Association.

Vermelho, L.L., Mello Jorge, M.H.P., 1996. Youth mortality: 1930-1991 period analysis (the epidemiological transition to violence). Revista de Saúde Pública 30 (4), 319-331.

Wacquant, L., 1992. Banlieues françaises et ghetto noir américain: de l'amalgame à la comparaison. French Politics and Society 10 (4), 81-103.

Wacquant, L., Wilson, W.J., 1989. The cost of racial and class exclusion in the inner city. Annals of the American Academy of Political and Social Science 50 (1), $8-25$.

Wallace, R., 1993. Social disintegration and spread of AIDS. Social Science and Medicine 38 (7), 887-896.

WHO, 1995. CID-10. OMS Tradução Centro Colaborador da OMS para Classificação de Doenças em Português, São Paulo: Editora da Universidade de São Paulo.

Zaluar, A., 2000. Exclusion and public policies: theoretical dilemmas and political alternatives. Revista Brasileira de Ciências Sociais, Special Issue 1, 25-42. 